口国際会議レポート

\title{
実践スポーツマネジメント学会 2018 年度大会 Applied Sport Management Conference 2018
}

\author{
前田和範（高知工科大学）
}

\section{1.はじめに}

2018 年 2 月 15 日から 17 日にかけて、アメリカ合衆国テキサス州ウェーコ（Waco）に位置す るベイラー大学にて、実践スポーツマネジメント学会 2018 年度大会 (Applied Sport Management Association Conference 2018：以下ASMA と略す）が開催された。ASMA は、2005 年から 2015 年 までは、主にアラバマ州のトロイ大学などで Southern Sport Management Association Conference（以 下 SSMA と略す）として開催されてきており、2016年以降、新しく設立された Applied Sport Management Association に引き継がれ、引き続き主にアメリカ南部を中心に開催されている（表 1)。 Applied（実践）というタイトルにもある通り、本学会は「研究者と実務家の強いつながりを構築 すること」を目的としている学会であり、今年度の基調講演に登壇した NCAA（全米体育協会） Division I・ビッグ 12 カンファレンスのコミッショナー・Bob Bowlsby 氏をはじめ、パネルディス カッションにも多岐にわたる実務家と研究者を招いて濃密なディスカッションが行われた。ASMA はアメリカに拈ける国内学会大会という色が強かったものの、特に海外からの若手研究者や実務家 の参加を歓迎している面もみられ、アジア・中東・ヨーロッパからも集まった総勢 143 名の参加者 によって、研究と実践に関する貴重な意見交換が行われた。

会場となったベイラー大学は、ダラス・フォートワース空港より国内便を乗り継ぎ 1 時間程度の ウェーコ・リージョナル空港から、車で約 15 分の場所に位置している。ベイラー大学は創立 1845 年のテキサスで最も歴史のある大学であり、スポーツにおいてはNCAA Division I のビッグ 12 カ ンファレンスに所属する強豪大学である。特に、2014 年に新調されたアメリカンフットボール専 用のマクレーン・スタジアムは 4 万 5 千人超のキャパシティを誇るベイラー大学ベアーズの本拠地 として、町の中心に流れるブラゾス川沿いに建設され、美しい景観をつくっている。

表 1 過去の大会スケジュール

\begin{tabular}{|c|c|c|c|c|c|}
\hline Year & Host & Conference & Year & Host & Conference \\
\hline 2005 & Troy University, Troy, Alabama & SSMA & 2012 & Troy University, Troy, Alabama & SSMA \\
\hline 2006 & Troy University, Troy, Alabama & SSMA & 2013 & Troy University, Troy, Alabama & SSMA \\
\hline 2007 & Troy University, Troy, Alabama & SSMA & 2014 & Bridgestone Arena, Nashbille, Tennessee & SSMA \\
\hline 2008 & Troy University, Troy, Alabama & SSMA & 2015 & Louisiana State University, Baton Rouge, Louisiana & SSMA \\
\hline 2009 & Troy University, Troy, Alabama & SSMA & 2016 & Louisiana State University, Baton Rouge, Louisiana & ASMA \\
\hline 2010 & Troy University, Troy, Alabama & SSMA & 2017 & Louisiana State University, Baton Rouge, Louisiana & ASMA \\
\hline 2011 & Troy University, Troy, Alabama & SSMA & 2018 & Baylor University, Waco, Texas & ASMA \\
\hline
\end{tabular}


今大会のスケジュールは表 2 の通りであり、初日はベイラー大学が擁するスポーツ施設を視察で きるアスレティック・ファシリティ・ツアーからスタートした。735 エーカーを誇る広大なキャン パスに点在するベイラー・ボールパーク（野球専用スタジアム）、ハード・テニス・センター（2,000 人以上の観客を收容できる 12 面の屋外テニスコート) などの主要施設の他、サッカー専用スタジ アム、ソフトボール専用スタジアムを経て、マクレーン・スタジアムを専用カートで回った。ガイ

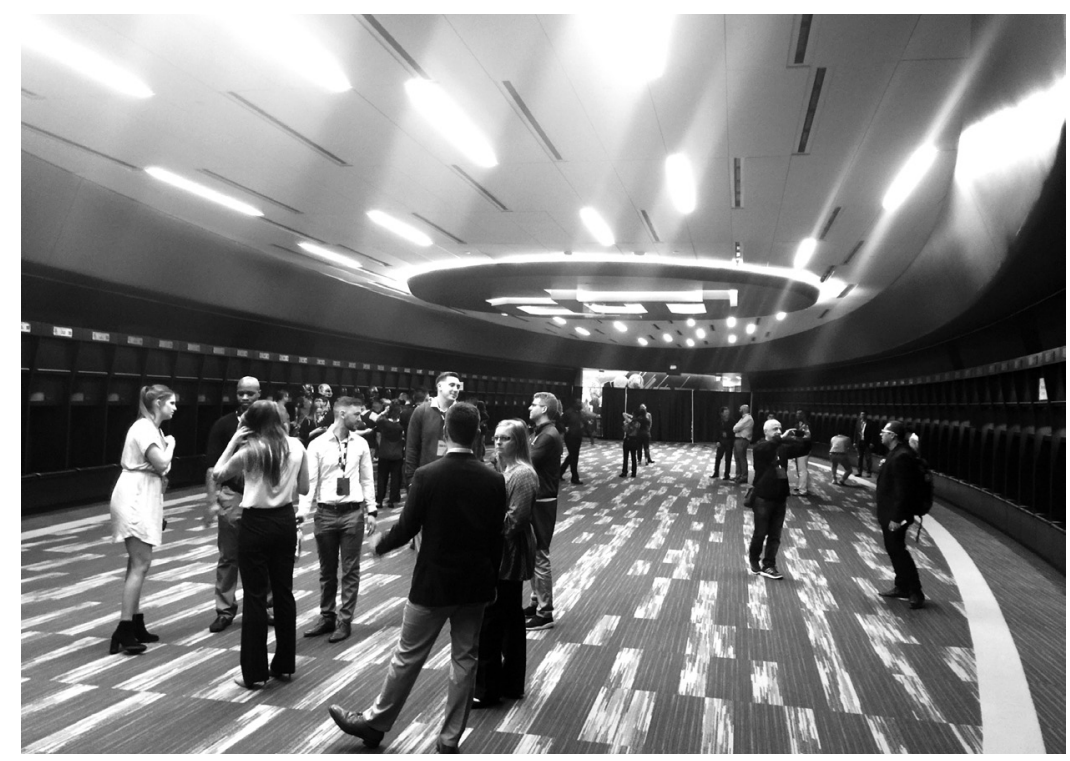

写真 1 マクレーン・スタジアム内のアメリカンフットボール専用ロッカールーム

\section{表 2 大会概要}

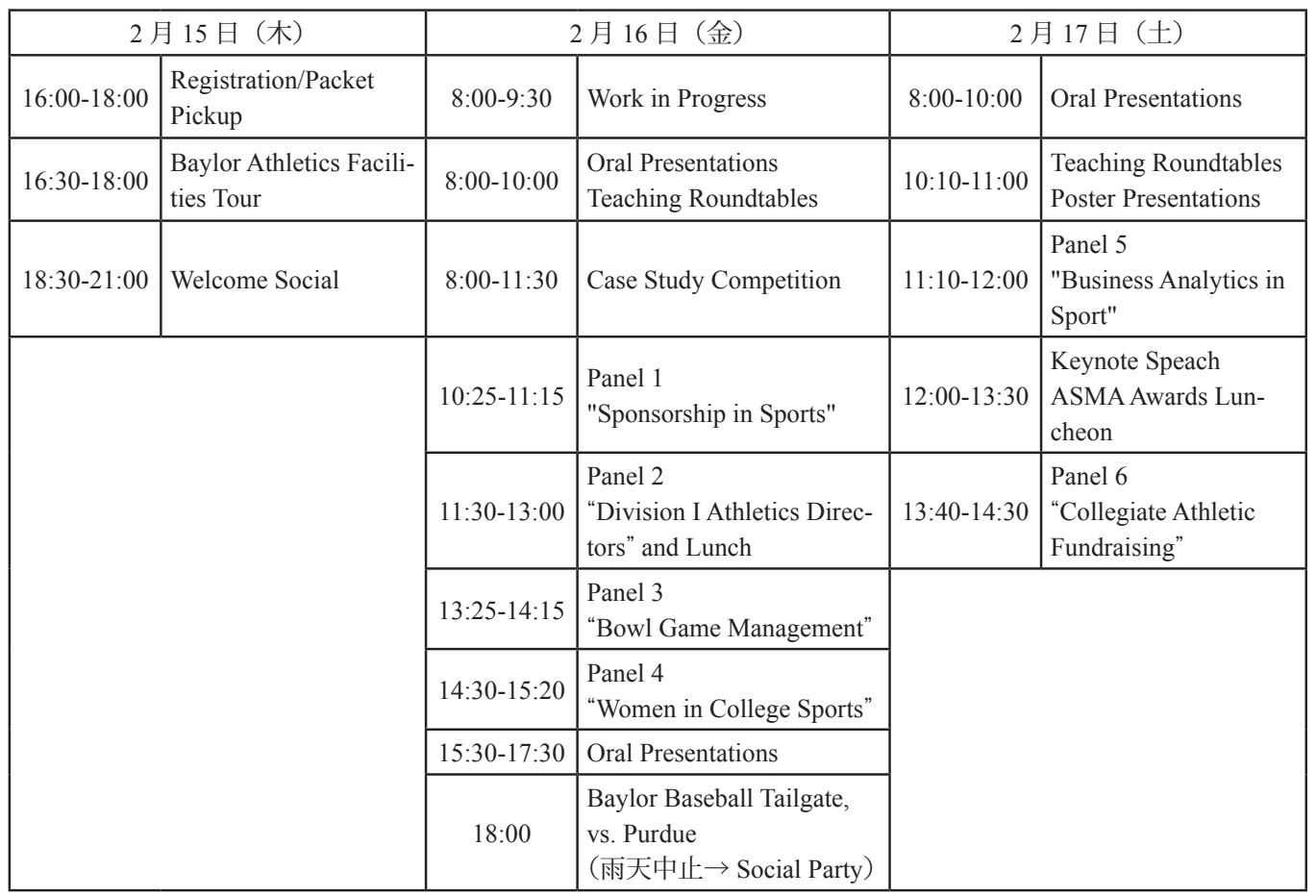


ド役はすべてベイラー大学スポーツマネジメントコースの学生であり、そのきめ細やかな説明と対 応から、教育の質の高さが伺えた。マクレーン・スタジアム内のスタジアムツアーでは、参加者は 名門アメリカンフットボール部の大規模なロッカールームに息を飲み、実際にフィールドや記者会 見ルーム、報道席などを視察した後、上階部に完備されているVIP ルームにて行われたウェルカ ムパーティーに参加した。

\section{2. 基調講演}

今大会の基調講演は、NCAA Division I・ビッグ 12 カンファレンスのコミッショナーである Bob Bowlsby 氏により行われた。講演のテーマは「巨大化する大学スポーツの現状と課題と将来につい て」であった。会場となったベイラー大学が所属するビッグ 12 カンファレンスは、NCAA の中で も上位に位置するカンファレンスでもあることから、パネルディスカッションや一般研究発表を通 しても、大学スポーツに焦点を当てた議論が数多く見られた。

Bowlsby 氏は、大学スポーツを「高等教育とアスレティックの両立を目指す極めて特異な存在」 と位置づけ、その取り巻く環境の変化と課題を述べた。特に、「大学生アスリートはあくまでも一 般学生である」ことを強調した上で、カンファレンス自体が巨額の資金を报うことからも、ビジネ ス色を帯びる中での大学スポーツマネジメントの難しさを述べた。また、すでに多くのステークホ ルダーを巻き込んでいるカンファレンスマネジメントでは、一つ一つの企業との関係性も複雑化し ているという外部課題に加え、カンファレンスに所属する大学ごとに特徴が異なるため、カンフ アレンス全体として得た便益がそれぞれの大学にとって等しく価值のあるものとは限らないことな ど、内部課題も同時に存在していることにも焦点を当てた。

今後のカンファレンスの展望としては、テクノロジーの成長によって目まぐるしく変化するスポ 一ツ消費者の消費環境を適切にとらえ、事業を最大化していく経済的側面にさらなる力を入れるこ とはもちろん、むしろそれよりも社会的側面、つまりカンファレンス自体の社会的地位を高めるこ との優先順位を上げていくことが不可欠である、と Bowlsby 氏は語った。基調講演は最後に、「大 学スポーツは、若者たちの人格を形成し、時に人種の壁をも無くすプラットフォームにもなり得る、 社会的価值の高いものであることを表現し続けなければならない。今後もその公益性という観点を 忘れてしまっては、ステークホルダーの理解は得られず、衰退の一途をたどってしまう。」という 言葉で締めくくられた。

研究者との今後の連携に関しては、カンファレンスとしても、現場の声に即したリサーチデザイ ンとその方法の継続的な開発に積極的に関わっていくとともに、それぞれの大学が「公正な大学入 ポーツ運営とは何か」という問いを立て続けることができるよう様々なサポートをしていきたいと 述べられていた。現在、日本でも大学スポーツに関する動きは活発化しており、日本版 NCAA 設 立の機運が高まっている。そうした中で、世界的にも大きなカンファレンスを束ねるコミッショナ 一による基調講演は、参考となることが非常に多く有意義なものであった。

\section{3. パネルディスカッション}

本学会では、6つのパネルディスカッションが行われた。いずれも発表者は研究者と実務家の共 同グループ、もしくは実務家で構成されていたものが多かったことも本学会の特徵と言えよう。内 容は、「Sponsorship in Sport（スポーツスポンサーシップ)」、「Division I Athletics Directors (NCAA 
Division I アスレティックディレクター)」、「Bowl Game Management（アメリカンフットボールゲ ームマネジメント)」、「Women in College Sports（大学スポーツにおける女性）」「Collegiate Athletic Fundraising（大学スポーツにおけるファンドレイジング)」「Business Analytics in Sport（スポーツ に扔けるビジネス分析)」であった。その中から、本項では 3 つのセッションについて略説したい。 「Sponsorship in sport」では、ベイラー大学教授でスポンサーシップ・セールスのディレクター を務める Dr. Kirk Wakefield 氏がスポンサーシップ研究の動向を詳細に語るとともに、ベイラー大 IMG（インターナショナル・マネジメント・グループによる大学連携機構）の GM やテキサスク リスチャン大 $\mathrm{IMG}$ の GM、そして地元マイナーリーグ 3A 所属ラウンドロックエクスプレスの GM を招き、今後のスポーツスポンサーシップのあり方について議論された。中でも、基調講演でも語 られたように、ビジネスの促進よりも地域や組織の社会課題の解決などに着目したスポンサーシッ プの形態が顕著である、という議論が活発に行われたことが印象的であった。

「Division I Athletics Directors」では、ベイラー大学、アビリーンクリスチャン大学、ノーステキサ ス大学から、それぞれアスレティックディレクターにより、各人の現在のポジションに就いた経緯 や、今後も複雑化する高等教育とアスレティックの両立についての議論が交わされた。どのディレ クターも、学生の競技レベルが上がり注目を集め、彼らのプロとのつながりが増えていくにつれ、 いかに学生一人一人のケアをするシステムを構築し運用していくかが重要であると述べ、自身のア スレティックディレクターとしての役割の重要性を共有した。

「Bowl Game Management」では、毎年行われる大学アメリカンフットボールのプレイオフでのゲ 一ムオペレーション担当とマーケティング・ブランドマネジメント担当、アラモボウル（ビッグ 12 ・パック 12 カンファレンスのチャンピオン同士が対戦するイベント）のマーケティング担当、 アメリカ大手のスポーツ専門チャンネル ESPN のイベント担当によって議論が行われた。大学のア メリカンフットボールイベントは他のスポーツイベントとは異なり、各部の OB やその地域の人々 のアイデンティティがぶつかり合うことによる強力なコンテンツであることから、取り巻く環境を 理解した適切な運営とターゲットを絞ったマーケティングが必要であり、メディア価值はその結果 として高まっていることが強調された。

\section{4. 一般研究発表}

2 日目の朝からスタートした一般研究発表では、口頭発表 27 題、ポスター発表 45 題の計 75 題 の発表が行われた。アメリカからの発表者が中心であったが、イギリス、トルコ、韓国、レバノ ンからも発表者が集った。日本からの発表者は前田和範氏（筆者：高知工科大学）1名のみが参 加し、「Exploration and Conceptualization of a Sense of Community as Responsibility to the Hometown of Members of Professional Sports Organizations（プロスポーツ組織のメンバーにおける、ホームタウン に対する責任としてのコミュニティ感覚の概念化)」という発表タイトルで口頭発表を行った。

本大会では予め研究分野が分類されていなかったため、相澤（2016）を参考に、北米スポーツマ ネジメント学会（North American Society for Sport Management Conference：以下NASSM と略す）の 研究分野別動向に基づいた分類を試みた。研究分野別、国別の発表件数の詳細は表 3 の通りである。 全体の動向としてはNASSM と同様、マーケティング分野の研究発表が最も多く（29.2\%）、次いで マネジメントノリーダーシップ分野が多かった (16.7\%)。その他も傾向としては概ね NASSM と類 似していたが、ASMA では特にポスター発表を中心に、ファイナンス分野が次に多い結果となっ た $(11.1 \%)$ 。 
表 3 研究分野別・国別発表件数

\begin{tabular}{|c|c|c|c|c|c|}
\hline 分野 & ASMA2018 & $\begin{array}{c}\text { 比較： } \\
\text { NASSM2016 }\end{array}$ & 国名 & & 件数 \\
\hline マーケティング(Marketing) & $21 \quad(29.2 \%)$ & $89(26.3 \%)$ & アメリカ & 64 & $(88.9 \%)$ \\
\hline マネジメントノリーダーシップ(Management/Leadership) & $12(16.7 \%)$ & $44(13.0 \%)$ & イギリス & 2 & $(2.8 \%)$ \\
\hline 社会・文化的側面(Socio-cultural) & $4(5.6 \%)$ & $47(13.9 \%)$ & トルコ & 2 & $(2.8 \%)$ \\
\hline 組織論／組織文化（Organizational Theory/Culture） & $6(8.3 \%)$ & $28(8.3 \%)$ & 韓国 & 2 & $(2.8 \%)$ \\
\hline 人材の多様性(Diversity) & $5(6.9 \%)$ & $20(5.9 \%)$ & レバノン & 1 & $(1.4 \%)$ \\
\hline 専門的職業準備(Professional preparation) & $5(6.9 \%)$ & $16(4.7 \%)$ & 日本 & 1 & $(1.4 \%)$ \\
\hline コミュニケーション(Communication) & $0 \quad(0.0 \%)$ & $20(5.9 \%)$ & 合計 & & 72 \\
\hline ガバナンス(Governance) & $5(6.9 \%)$ & $10(2.9 \%)$ & & & \\
\hline 経済学(Economics) & $2(2.8 \%)$ & $14(4.1 \%)$ & & & \\
\hline 教授学(Teaching) & $1(1.4 \%)$ & $13(3.8 \%)$ & & & \\
\hline スポーツ・ツーリズム(Sport Tourism) & $1(1.4 \%)$ & $10(2.9 \%)$ & & & \\
\hline 研究法 (Research/Statistical methodology) & $0 \quad(0.0 \%)$ & $9(2.7 \%)$ & & & \\
\hline 法的問題(Legal aspects) & $0 \quad(0.0 \%)$ & $8(2.4 \%)$ & & & \\
\hline 金融論(Finance) & $8(11.1 \%)$ & $3(0.9 \%)$ & & & \\
\hline 倫理学(Ethics) & $2(2.8 \%)$ & $8(2.4 \%)$ & & & \\
\hline 合計 & 72 & 339 & & & \\
\hline
\end{tabular}

マーケティング分野では、主に NFLや MLB（メジャーリーグベースボール）だけでなく、 NCAAのファンの分類やモチベーションに関する研究が多く見受けられた。マネジメント分野では、 スタジアムマネジメントに関する研究や、スポーツ管理者のリーダーシップに関する研究が多く見 られた。ファイナンス分野では、主にプレイヤーのサラリーに関する研究が目立っていた。大学ス ポーツを対象にした研究が多かったこともあり、選手育成やインターンシップに関する専門的職業 準備分野の研究や、スポーツマネジメントのカリキュラムに着目した教授学分野の研究、青少年や ユース世代のモラルに関する倫理学分野の研究も印象深かった。

\section{5. まとめ}

本稿では、ASMA における基調講演、パネルディスカッション、一般研究発表について略説した。 ASMA は、NASSM やEASM（ヨーロッパ・スポーツマネジメント学会）などの学会大会と比較す ると小規模ではあったものの、濃密な議論が交わされていたことが印象的であった。NCAAの規 模の大きさを改めて実感するとともに、そこに関わる研究者やアスレティックディレクターをは じめ、実務家であるカンファレンスコミッショナーや IMG の GM、マイナーリーグ所属チームの GM が口を揃えて「スポーツは社会の中の一部であることを理解しなければならない」と語ってい たことに、アメリカスポーツの懐の深さを感じた。現代では産業化が進みテクノロジーも発達した ことにより、消費者の取り巻く環境は絶えず変化している中で、それぞれのスポーツ組織が自らの 関わるスポーツの立ち位置や価值を客観的に分析することの必要性をあらためて痛感した。

ASMA は若手研究者に門戸を開いている印象も強く、著者自身、単身で海外の学会大会に参加 した経験は初めてではあったものの、多くの研究者や実務家とも出会うことができ、得られるもの が多かった学会大会であった。開催時期が 2 月ということもあり、日本の大学によっては比較的参 加しやすい日程であることからも、今後もより多くの研究者、大学院生、学生が参加され、研究と 
実践における貴重な議論が交わされることを期待したい。

来年度の ASMA は 2019 年 2 月 14 日から 16 日まで、アメリカ合衆国テネシー州ナッシュビルの ベルモント大学にて開催される予定である。

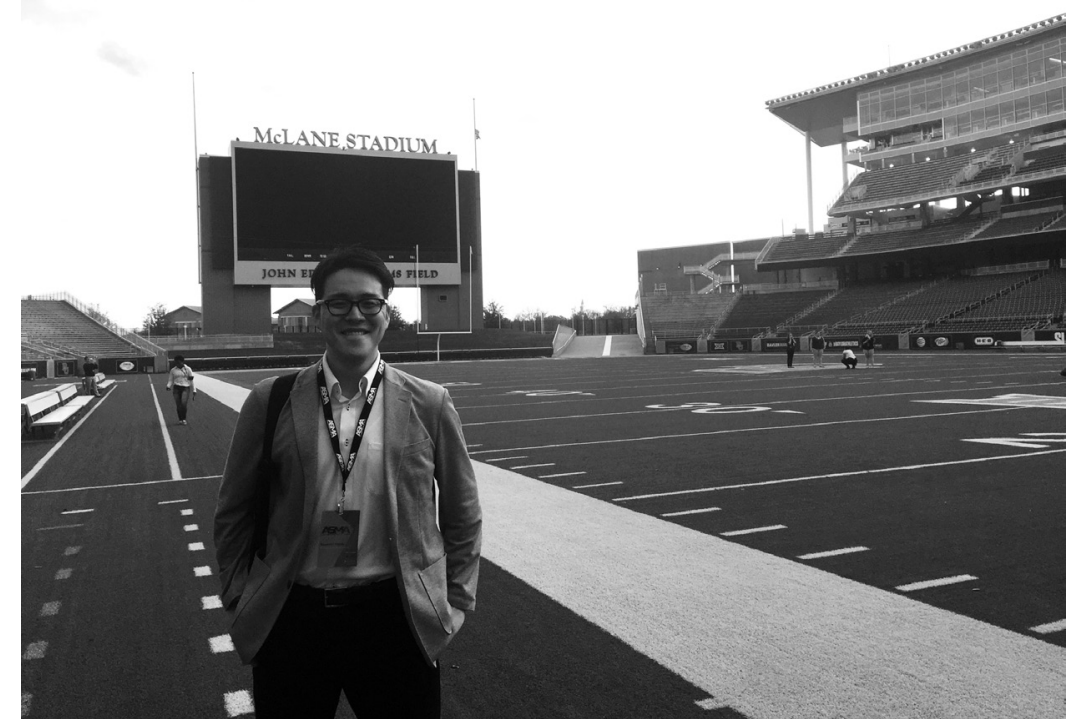

写真 2 マクレーン・スタジアムのフィールドにて (著者)

\section{【参考文献】}

相澤くるみ（2016）国際会議レポート 北米スポーツマネジメント学会 2016 年度大会, スポーツマネジメ ント研究, 9 (2), 35-39. 